\section{Verdifullt om arytmier}

Karin Køltzow, Liv Hopen Hjertebank og hjerteklapp

Kunnskap og råd ved arytmier. 124 s, ill. Oslo: JAS forlag, 2010. Pris NOK 200 + porto ISBN 978-82-998459-0-8

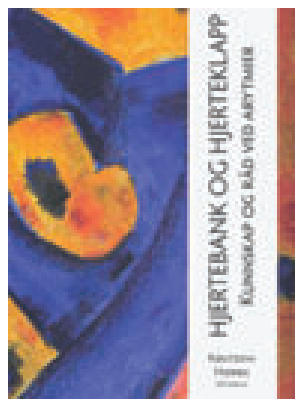

Dette er en lettlest og velskrevet bok med kunnskap og råd ved arytmier. Spesielt kunnskapsdelen er kortfattet og instruktiv. Boken inneholder gode råd for bruk av meditasjon, pusteøvelser, rikelig med mosjon etc.

Problemet med pasienter med arytmi er imidlertid at de representerer en meget heterogen gruppe. Det er alt fra uskyldige ekstrasystoler og friske hjerter via atrieflimmer uten hjertelidelse for øvrig til alvorlig hjertesykdom kombinert med plagsomme arytmier. Det er klart at pasientene må ha individualisert behandling. Forfatterne kunne trolig ha lagt enda mer vekt på hvor viktig det er å få en korrekt diagnose av den hjertetilstanden som er assosiert med arytmien hos den enkelte pasient. Slik boken fremstår, synes jeg at den tenderer til å skjære alle pasienter med arytmi over en kam.

Didaktisk sett er den fint lagt opp med mye god informasjon $i$ åtte oversiktlige kapitler. Illustrasjonene er gode, og kasuistikkene liver opp. De virker imidlertid nokså selekterte i retning av rene arytmipasienter uten ledsagende hjertelidelse.

Det er greit nok å gå en tur for å bli kvitt ekstrasystoler. Imidlertid kan opptreden av ekstrasystoler under belastning være et tegn på alvorlig, tilgrunnliggende koronarsykdom uten at pasienten nødvendigvis merker brystsmerter.

Forfatterne oppsummerer med at atrieflimmer og atrieflutter er godartet, men at det kan være en plagsom, ofte aldersbetinget rytmeforstyrrelse hos mange. I de siste europeiske retningslinjene for atrieflimmer står det innledningsvis: «Atrieflimmer representerer en fem ganger økt risiko for hjerneslag, og ett av fem hjerneslag skyldes denne arytmi. Hjerneslag assosiert med atrieflimmer er ofte dødelige, og de som overlever er ofte mer invalidiserte enn de som har hatt hjerneslag av andre årsaker. Videre har pasienter med atrieflimmer dobbelt så høy dødelighet som de uten. Atrieflimmer er assosiert med økt hyppighet av blodpropper, hjertesvikt, sykehusinnleggelser, redusert livskvalitet og redusert fysisk kapasitet.» (1). Hvordan dette kan beskrives som en godartet tilstand, er utenfor min fatteevne.

Når det gjelder utsagnet om at risiko for «blodpropp som flimmer gir, kan holdes i sjakk med blodfortynnende midler» (s. 35), må vi huske at det ikke dreier seg om en $100 \%$ risikoreduksjon. Den relative risikoreduksjonen av hjerneslag sammenliknet med ingen antikoagulasjon ligger $\mathrm{i}$ henhold til de nye retningslinjene i størrelsesorden $65-70 \%$. Når det er nevnt, syns jeg at kapitlet om antikoagulasjonsbehandling er meget bra og informativt.

Ellers er omtalen av mestring og Eli Bergs verdifulle arbeider veldig god. I den sammenhengen må man hele tiden ha for seg hvilken arytmikategori og ledsagende hjertelidelse den enkelte pasient representerer.

Kort summert inneholder boken mye verdifullt stoff, som for meg virker mest tilgjengelig for yngre pasienter med arytmi uten alvorlig hjertelidelse. Mye kan være tungt og uaktuelt for mange eldre, spesielt de med ledsagende hjertesvikt, følgetilstander etter hjerneslag og/eller andre kardiovaskulære manifestasjoner.

\section{Jan Erik Otterstad \\ Hjerteseksjonen}

Sykehuset i Vestfold

\section{Litteratur}

1. Camm AJ, Kirchhof P, Lip GY et al. Guidelines for the management of atrial fibrillation: the Task Force for the Management of Atrial Fibrillation of the European Society of Cardiology (ESC). Eur Heart J 2010; 31: 2369-429.

\section{Pasientperspektiv på sykdom og lidelse}

Anne-Mette Graubæk, red.

\section{Å være pasient}

En innføring i pasientologi. 230 s, tab, ill. Oslo: Akribe, 2010. Pris NOK 370 ISBN 978-82-7950-147-3

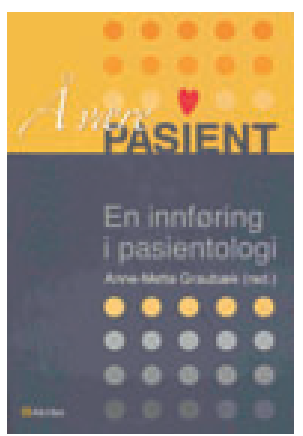

Ni danske sykepleieforskere har skrevet hver sine kapitler rundt tematikken pasientologi. Dette begrepet ble introdusert av den amerikanske sykepleieren Pamela Brink i 1978. Hun var «indignert over pleiepersonalets negative holdninger overfor pasienter - nedlatende, moraliserende», og at de hadde en forståelse av mange pasienters lidelser som selvforskyldte. Pasientologi handler om pasientens perspektiv, pasientrollen, pasientens kulturelle kontekst og offerrollen. Viten om pasientologi skulle hindre at «personalet påførte pasientene pleielidelse», altså at de unngikk å krenke pasientene.

Forfatterne begrenser seg til voksne pasienter og til somatisk sykdom. Boken åpner med fire pasienters egne fortellinger. Personene beskriver hvordan de opplever egen situasjon med henholdsvis alvorlig ryggmargsskade, kronisk nyresykdom, alvorlig kreftsykdom og livet etter hjerneblødning. Deretter følger de ulike forfatternes teoretiske bidrag: empirisk funderte teorier om det å være syk, analyse av fortellinger, det å komme videre i livet, den fysiske avhengigheten når kroppen svikter, «vanskelige» pasienter, pårørendes rolle, pasientutdanning, og til slutt en historisk gjennomgang av pasient- og hjelperkulturen de siste 100 årene.

Hvert nytt kapittel innledes med et foto i svart-hvitt av et menneske i en situasjon som skal tematiseres. Dette er både vakkert og talende for teksten som følger, en tekst som så vel er lettlest som logisk oppbygd. Etter hvert bidrag følger en litteraturliste.

Er dette en bok for leger? Forfatterne har et ønske om å belyse hva det vil si for et menneske å bli akutt, langvarig eller alvorlig syk, hva dette kan resultere i, i form av en «personlig prosess med kontrolltap, gjennomgripende forandringer i livet og begrensninger relatert til kroppen, selvet, til tids- og romoppfatning og til relasjoner til andre mennesker» - alle svært sentrale emner for medisinstudenter og leger - også for erfarne kolleger i og utenfor sykehus. Kanskje er ikke dette en tematikk som har den største plassen i medisinstudiet eller i videre- og etterutdanningen for leger? Men pasientens perspektiv er aktuelt i ethvert møte med mennesker som søker lege. Når vi nå etter hvert får stadig mer kunnskap og forståelse av betydningen av menneskets biografi for vår biologi, kan denne boken være en spore til ytterligere drøftinger og forskning innenfor dette vesentlige området.

Om vi skal ha et eget begrep - pasientologi - for dette, er jeg mer usikker på. Pasientperspektivet må ikke isoleres fra resten av fagfeltet medisin. Men uansett fortjener forfatterne honnør for å ha bidratt med en innsiktsfull påminnelse om hva helsevesenets oppgave er: å bistå mennesker til å bevare eller gjenvinne helsen, eller å få en verdig avslutning på livet.

\section{Eli Berg}

Senter for helsefremmende arbeid

Akershus universitetssykehus 